\title{
Establishing Core Factors of Risk Management Influencing Performance Outcome of Small and Medium Firm's Construction Projects in Gauteng
}

\author{
*Berenger Yembi Renault', Justus Ngala Agumba² and \\ Nazeem Ansary ${ }^{2}$
}

First submission: 30 May 2019; Accepted: 12 December 2019; Published: 15 December 2020

To cite this article: Berenger Yembi Renault, Justus Ngala Agumba and Nazeem Ansary (2020). Establishing core factors of risk management influencing performance outcome of small and medium firm's construction projects in Gauteng. Journal of Construction in Developing Countries, 25(2): 93-127. https://doi.org/10.21315/jcdc2020.25.2.4.

To link to this article: https://doi.org/10.21315/jcdc2020.25.2.4

\begin{abstract}
The quest for delivering successful construction projects has urged South African small and medium enterprises (SMEs) to adopt risk management in their projects. However, it has been evinced that SMEs projects in South Africa especially in the Gauteng province have encountered poor performances. Thus, this article determines core risk management factors influencing project outcome of SMEs. A deductive approach was embraced using a questionnaire. The data were collected from 181 conveniently sampled respondents in Gauteng, graded from Grade 1 to 6 of the CIDB (Construction Industry Development Board) grading system. The Statistical Package for the Social Science (SPSS) version 23 was used to analyse the data by computing exploratory factor analysis and multiple regression analysis. It was revealed that SMEs performance outcome is influenced by eight risk management factors. The influential factors are organisational environment, defining project objectives, resource requirements, risk measurement, risk identification, risk assessment, risk response and action planning and monitoring, review and continuous improvement. The risk management factors established in this article are reliable and valid in projects undertaken by SMEs in the South African construction industry and the findings can serve as a guideline for contractors to achieve success in this context. The study may be repeated in other countries globally, however, it cannot be generalised due to the restrictions pertaining to the geographical area.
\end{abstract}

Keywords: Construction, Performance outcome, Risk management factors, Small and medium enterprises

\section{INTRODUCTION}

Risk management in construction has been an important issue for many years and therefore has become, according to Al-Shibly, Louzi and Hiassat (2013), an area of concern for the construction industry. This development has been in general due to the risk associated with the delivery of construction projects and the recurrence of poor project performances (in the form of project cost and time overruns, poor quality achievement, project not meeting technical requirement and clients not satisfied) especially among small and medium enterprises (SMEs) whose contribution to the growth of a country's economy is substantial globally (Fischer, 2015; Smit, 2012).

\footnotetext{
'Department of Construction Management and Quantity Surveying, University of Johannesburg, Auckland Park 2006, SOUTH AFRICA

${ }^{2}$ Department of Building Science, Tshwane University of Technology, Pretoria, SOUTH AFRICA

"Corresponding author: renault08@yahoo.fr
} 
The small and medium enterprise (SME) sector is the largest provider of employment in most nations, particularly in the creation of new jobs (Fan, 2003). A report released by the UN-Habitat (United Nations Centre for Human Settlements) (1996) indicates that $91 \%$ to $93 \%$ of industrial firms in the South East and East Asian countries are SMEs. In Russia and some parts of Europe, SMEs employ up to 250 employees and represent roughly $90 \%$ of the total number of firms that provide $45 \%$ of the total employment and generate $40 \%$ of the total sales (Fan, 2003). In South Africa, SMEs make up $97 \%$ of all firms; as a result, they contribute $35 \%$ of gross domestic product (GDP) and employ 55\% of the country's labour force (Statistics South Africa, 2014). The SME construction sector is equally important to the South African economy as that of SMEs in general. In South African construction industry, $78.5 \%$ of firms are SMEs and the industry employed 1,395,000 people (formal and informal sectors), accounting for $9 \%$, 6\% on average of GDP between 2008 and 2016 (Statistics South Africa, 2017). The SME sector is undoubtedly vital in job creation and the well-being of the economy. Despite SME involvement, Van Scheers (2011) found that $40 \%$ of these firms fail in their first year of business, $60 \%$ in their second year and $90 \%$ in their first 10 years of business. These figures include construction SMEs. However, the Construction Education Training Authority and CIDB (Construction Industry Development Board) indicate that in South Africa, $70 \%$ of construction SMEs fail in their first year of existence (Martin, 2010).

Studies conducted indicate that the factors that contribute to the high failure rate of construction SMEs are numerous and diverse. Some studies (Chen, 2006; Luo, 2003) mention compliance with legislation, resource scarcity, rapidly changing technology, lack of management skills, financial knowledge and lack of management commitment. Other factors experienced in the SME sector include managerial incompetence, lack of managerial experience, inadequate planning and poor financial control (Aigbavboa, Tshikhudo and Thwala, 2014). However, Fischer (2015) found that in South Africa, SMEs lack the skills to implement risk management and are generally inadequately equipped to deliver on projects. Supporting this statement, Fischer (2015) opined that informal SMEs are far more likely to employ lower educated individuals. This reinforces the impression that SMEs lack the required skills to implement risk management effectively at the project level. Similar studies indicate that SMEs have acute shortages of risk management knowledge and skills, implementation of risk management practices and ultimately risk management capability (Gao, Sung and Zhang, 2011). Corroborating this approach to risk management, Poba-Nzaou and Raymond (2011) believe that SMEs tend to use a "reactive, informal or seemingly unstructured and intuitive approach" to manage risk when compared to large firms.

In order to surmount these challenges, Marcelino-Sádaba et al. (2014), Masutha and Rogerson (2014) and Fischer (2015) suggested that SMEs need to be conversant with risk management factors which are deemed to influence performance outcome at the project level. Fischer (2015) study recommended three factors of risk management required for South African construction SMEs. These were construction partnering, shared risk management and retention of knowledge in construction. In a study by Smit (2012), four factors were identified which included strong support to risk management activities, clearly defined and communicated expectations, alignment of the risk management with the organisation's overall business strategy and integration of the risk management into the organisational processes. However, Fischer (2015) and Smit (2012) studies did not determine the influence of risk management factors on performance outcome of construction 
SMEs in South Africa. Moreover, Fischer (2015) and Smit (2012) risk management factors diverged from other researchers (Kishan, Bhatt and Bhavsar, 2014; Ngundo, 2014; Phoya, 2012; Papke-Shield, Beise and Quan, 2010; Oztas and Okmen, 2005). The use of varied risk management factors among authors is an indication of the lack of unanimity on the risk management factors that impact on the successful outcome of SMEs projects. It can further be deduced that there is a scarcity of analytical studies, comparing suitable factor models using exploratory factor analysis (EFA) that is ideal for SMEs projects.

The current study thus compares analytically the fitting performance model of risk management that best predicts the successful outcome of SMEs projects. The following section provides an overview of the risk management factors and the performance outcome.

\section{RISK MANAGEMENT IN SMES}

The World Bank Group discloses that between 365 million to 445 million of the enterprises in emerging markets are micro, small and medium-sized enterprises (World Bank Group, 2017). A report released by the Small Business Institute shows that $98.5 \%$ of the South African economy is made up of SMEs and that their share in the South African construction industry is considerable (Writer, 2018). The economic growth of emerging economies is enormously dependent upon the development of SMEs and that their "productivity growth is fuelled by competitive processes in the industry which, to a large extent, is built on the birth and death, entry and exist of smaller firms" (World Bank Group, 2017).

Verbano and Venturini (2013) stated that all enterprises including SMEs need to adopt risk management strategy in order to identify, assess and respond to potential threats. SMEs lack resources to respond promptly to hazards which have the potential to engender massive losses and even bankruptcy of the fi risk management (Masutha and Rogerson, 2014). As a result, they need to practice risk management much more than their larger competitors (Masutha and Rogerson, 2014; Gao, Sung and Zhang, 2011). However, in order to attain a competitive edge and increase the rate of success of their business, SMEs need to make risky decisions and participate in risky activities so that they can protect the innovativeness of delivering projects (Van Scheers, 2011). Furthermore, SMEs encounter more uncertainties and challenges than their larger competitors which make these enterprises to consider risk management as an integral part of the business management to keep the firms viable and productive (Smit, 2012).

\section{What is Risk Management?}

Risk management denotes a coordinated set of activities and procedures that is employed to direct an organisation and to control possible events that may prevent projects from achieving established objectives (de Bakker, Boonstra and Wortmann, 2011). Risk management is further defined in ISO 31000 as the identification, assessment and prioritisation of risks followed by coordinated and economical application of resources to reduce, monitor and control the possibility and/or impact of unfortunate events (Gao, Sung and Zhang, 2011). Risk management therefore, informs project team members on how they could manage risk, what resources 
are required and the cost to manage these risks (Mahendra, Pitroda and Bhavsar, 2013). This definition is also summed up by "the way organisations anticipate on potential threats to projects" (Phoya, 2012).

It is essential to note that there is always some risk management of procedure that an organisation follows to protect itself against unwanted events. The only thing is that the approach to risk management and methods employed to manage risks may vary among organisations. Naidoo (2012) indicated that organisational risk management exists on a continuum and that organisations can either have a good or poor risk management performance. Project risk management can also be referred to as the subset of an organisation's enterprise risk management plan (Karimi et al., 2010; Lee-Anne, 2007). Omphile (2011) opined to that the necessity to manage risk in construction is continuously growing owing to various reasons which include but not limited to the intricacy, competition, size, politico-economic challenge and client-consumer requirements. Hence, the operationalisation of risk management in the construction industry cannot be overlooked. However, for risk management to be operationalised, it is pivotal to know what influence it.

\section{Factors of Risk Management}

What should constitute risk management is one area where perplexity has reigned in literature of risk management. This is in part because of innumerable terms that have been employed to illustrate the activities undertaken in the risk management process. Some studies have referred to the parts which form, shape or make up risk management as indicators (Scarlat, Chirita and Bradea, 2012; Immaneni, Mastro and Haubenstock, 2004), factors (Beasley, Clune and Hermanson, 2005), elements (Deloach, 2018; Bilich, 2015; Agle, 2013) and attributes (Gordon, Loeb and Tseng, 2009; Jablonowski, 2001) of enhanced risk management. Thus, it is important to know what these terms mean to reduce partially the perplexity. The identified terms are defined as follows (Cambridge Advanced Learner's Dictionary, 2008):

1. Indicator (noun): something that shows what a situation is like.

2. Factor (noun): A fact or situation which influences the result of something.

3. Element (noun): A part of something, it is what makes up something.

4. Attribute(s) (noun): A quality or characteristic that someone or something has.

An examination of the above terms indicates that the term "factor" refers to a fact or situation that will contribute to a result. Hence referring to risk management, this term would denote an influence that has a bearing on the outcome of the project. In other words, without the factor it is impossible to achieve project objectives.

An "indicator" is described as something that shows what a situation is like or something that indicates the level of a result. Therefore, with reference to risk management, this could be certain exhibits that could be observed or measured to tell the level of improvement of risk management.

The terms "attribute" refers to the description of a quality or "characteristic that someone or something has". Consequently, with reference to risk management this would refer to the quality or the particularity of an activity. 
This study sought to establish the factors of risk management influencing project outcome of SMEs. Having scrutinised the terms that have been employed in other studies and based on the definition of risk management mentioned previously, risk management can therefore be said to be composed of risk identification and assessment, risk prioritisation and application of resources to reduce the impact of unwanted events (Olamiwale, 2014; Liebenberg and Hoyt, 2003). These are the aspects that can be referred to as the elements of risk management generally. Agle (2013) correctly refers to three of these, namely; risk assessment, risk response and monitoring as elements of risk management. From the definition, an element is a part of something. These elements in turn influence or contribute to project risk management effectiveness.

As for the terms that would refer to aspects that constitute risk management and influence project outcome, the term "factor" is more appropriate as it denotes a fact or situation which influences the result of something.

The argument in this study is that it is much more beneficial, proactive and feasible to operationalise the concept of risk management by establishing the factors of risk management that influence construction project outcome. The task then is to identify these factors that are the key to risk management and thus be used as influencers of project outcome.

\section{Identifying Factors of Risk Management}

Risk management factors have been tremendously studied. For instance, Kamau and Mohamed (2015) evaluated the effectiveness of monitoring and evaluation function in attaining project outcome. They found four main factors which were referred to as the best project risk management practices namely managing communications, managing stakeholders, motivating and knowledge transfer. In their study, Oztas and Okmen (2005) established four core risk management elements influencing project success namely risk management foundations, risk identification and assessment, risk measurement and reporting, and risk mitigation. According to the authors, each of these elements should be developed and connected in order to work as an integrated whole.

Other risk management models revealed that personally focused cultural values, such as openness to change, rather than socially focused cultural values, such as self-transcendence (Kishan, Bhatt and Bhavsar, 2014), institutional system, organisational system, individual System and work environment system (Phoya, 2012) were significant to project team performance. It was observed that some of the factors in Phoya (2012) study could be a combination of several subfactors. For instance, work environment system could be explained by working tools/ methods/location, work teams, working procedure and physical space. Likewise, the institutional system could include policies/regulations and control mechanism (Papke-Shield, Beise and Quan, 2010); the organisational system could include policies on health and safety, management style and resource allocations (Berssaneti and Carvalho, 2015).

The factors identified by Kamau and Mohamed (2015), Oztas and Okmen (2004), Kishan, Bhatt and Bhavsar (2014) and Phoya (2012) may not be definite as they may not necessarily reflect the most important factors in other studies. The factors might be similar but have different measuring statements across different populations (Mahendra, Pitroda and Bhavsar, 2013). Moreover, there may be other 
important factors that the consulted sources are not addressing or indeed more appropriate questions within each factor, which makes the identified factors nonexhaustive.

In addition, other studies dwelt on factors such as senior management support, senior management competence (Maina et al., 2016), project funding and project risk planning (Ngundo, 2014). Although there is evidence of a plethora of factors in extant literature related to risk management, a more comprehensive description of the factors influencing project outcome in a broader sample of construction workers has not yet been conducted. It was not evident whether the risk management factors which were found to influence project outcome in previously used questionnaires truthfully represent the diversity of perceptions and that they will also influence performance outcome in construction projects of SMEs in South Africa.

Even though there was no study with similar factors, the review of the literature indicated that there is a consensus of a specific combination of risk management factors that influence the project outcome of SMEs. Furthermore, conclusions from other studies (as discussed previously) were observed to be comprehensive and adaptable for the current study. Based on this sentiment, nine independents risk management factors i.e. organisational environment, defining objectives, resource requirement, risk measurement, risk identification, risk assessment, risk response and action planning, communication and monitoring, review and continuous improvement that are perceived to influence project outcome of SMEs were identified and hypothesised.

\section{Defining a SME}

There is no general definition of a SME (Eyiah, 2001). When defining a SME, preference is first given to a qualitative or economic concept and that secondly, as a result of the need for statistical verification, certain maximum quantitative guidelines are laid down (Agumba, 2006). However, the statistical guidelines at times vary since small enterprises are very heterogeneous. Dlungwana et al. (2002) indicated that small construction enterprises in South Africa generate an annual turnover of less than R10 millions while medium enterprises have an annual turnover of between R10 millions to R50 million (fixed property excluded). As far as permanent employees and turnover, the National Small Business Act (1996) stipulates that for an enterprise to be considered as a small to medium sized enterprise it must have between 50 and 200 employees, a turnover ranging between R5 million and R20 million. The South Africa CIDB (2011) on the other hand defines small and medium enterprises as those enterprises which are owned, managed and controlled by formerly disadvantaged persons and does not classify them according to their financial capabilities. For the purpose of this study, small and medium enterprises were defined based on the number of permanent employees and turnover.

\section{Project Success Outcome}

Over the years, numerous studies have been conducted to evaluate the outcome measures of success in construction projects of SMEs. Most of those studies have suggested diverse outcome measures or parameters. For instance, the leading success outcome parameters according to Hinze. Thurman and Wehle (2013) 
and Toor and Ogunlana (2010) are scheduled time, budgeted cost and desired quality. These were referred to by $\mathrm{Ng}$ et al. (2009) as the "iron triangle". Toor and Ogunlana (2010) indicated that while other measures of project outcome have emerged, the iron triangle is nearly cited in every study on project outcome. This statement was supported by Collins and Baccarini (2004) who believed that success metrics in projects should not be restricted to just the iron triangle and the project management community should be aware of this. As a result, Chou and Yang (2012) defined project success outcome by four parameters of achieving design goals, the value to the end user, the value to the organisation, the value of the technological infrastructure of the country and of organisations implicated in the development process. Chou and Pham (2013) identified project outcome by seven metrics which included the iron triangle and other four metrics. The four metrics were: (1) affability of the environment, (2) transfer of technology, (3) client and project manager's satisfaction and (4) health and safety. According to Roelen and Klompstra (2012), the project is a complete success if it attains the technical performance specifications to be executed and if there is satisfaction regarding the project outcome among key users and project team members. The incorporation of satisfaction as a success metric is also recommended by Weninger et al. (2013). Berssaneti and Carvalho (2015) on the other hand suggested incorporating the absence of legal claims as a measure of successful outcome in SMEs projects. This indicates the importance of including safety as a success measure since it is logical to anticipate that if accidents materialise, both clients and contractors may be subject to financial loss, contract delay as well as legal claims. The use of diverse parameters of project success outcome is an indication that there is no consensus in the literature pertaining to the measures of defining project success in SMEs projects.

Despite the vagueness in defining project success outcome, this article identified five measures as tabulated in Table 1, i.e. meeting time objectives for key milestones, meeting cost objectives, meeting quality objectives, meeting required health and safety levels and meeting expected client's satisfaction levels for the project.

Table 1. Project Success Outcome Measures

\begin{tabular}{|c|c|}
\hline Project Outcome (PO) & Source \\
\hline $\begin{array}{l}\text { PO1: Meet time objectives for key } \\
\text { milestones }\end{array}$ & $\begin{array}{l}\text { Hinze, Thurman and Wehle (2013), Chou and } \\
\text { Pham (2013) and Toor and Ogunlana (2010). }\end{array}$ \\
\hline PO2: Meet cost objectives for the project & $\begin{array}{l}\text { Hinze, Thurman and Wehle (2013), Chou and } \\
\text { Pham (2013) and Toor and Ogunlana (2010). }\end{array}$ \\
\hline $\begin{array}{l}\text { PO3: Meet quality objectives for the } \\
\text { project }\end{array}$ & $\begin{array}{l}\text { Hinze, Thurman and Wehle (2013), Chou and } \\
\text { Pham (2013) and Toor and Ogunlana (2010). }\end{array}$ \\
\hline $\begin{array}{l}\text { PO4: Meet the required health and safety } \\
\text { levels }\end{array}$ & $\begin{array}{l}\text { Chou and Pham (2013) and Berssaneti and } \\
\text { Carvalho (2015). }\end{array}$ \\
\hline $\begin{array}{l}\text { PO5: Meet expected client's satisfaction } \\
\text { levels }\end{array}$ & $\begin{array}{l}\text { Chou and Pham (2013) and Weninger et al. } \\
\text { (2013). }\end{array}$ \\
\hline
\end{tabular}


The current study determines the influence of risk management factors on performance outcome in the context of construction SMEs in South Africa to develop a conceptual model of risk management at the project level. The study is expected to bridge the gap in the literature which indicates scant studies on risk management factors and their relationships with project outcome in construction. The factors identified in the study would enable a positive risk management culture to be experienced at the project level of SMEs and retain executive management attention in observing risk management practices during construction activities. The following section presents the model constructs identified in the review as well as their hypothesised relationships.

\section{Model constructs and hypothesised relationships}

Figure 1 presents the conceptual framework of risk management used in the study. The model depicts the influence of the core factors to project outcome as well as the hypothesised relationships between the constructs. On the other hand, project outcome is dependent on the level of practice of the identified factors. These theoretical constructs and their relationship with project outcome are discussed in detail and hypothesised as follows.

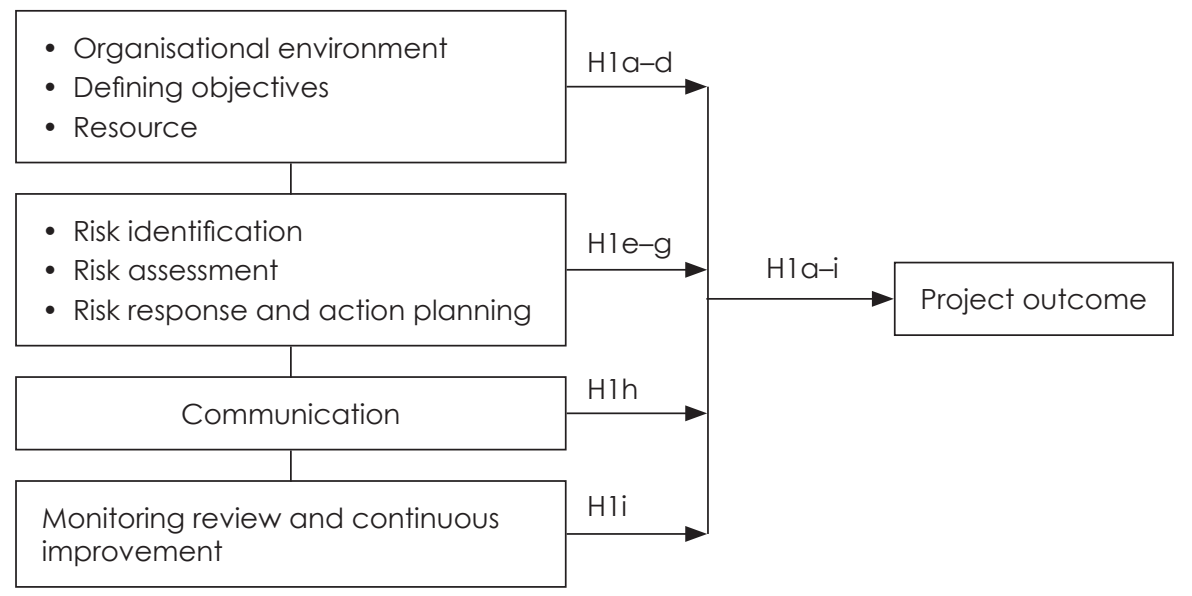

Figure 1. Conceptual Framework of Risk Management

\section{Relationship of organisational environment with project outcome}

Smit (2012) and Bosher et al. (2007) indicated that understanding the organisational environment of risk ensures that all organisational stakeholders understand their responsibilities and accountabilities and identify possible weak areas that may influence the project from achieving its objectives. As stakeholders' role is central to the success of any project, scholars studying the construction sector (Olander and Landin, 2005; El-Gohary, Osman and El-Diraby, 2006; Momeni, Hamidizade and Nouraei, 2015) have established that stakeholders' implication has indubitable impacts on project outcomes. Furthermore, in exploring the effect of organisational 
environment, top management involvement and stakeholder's involvement on the success of a project, Basu et al. (2002) observed that these factors were considerably related to project success. From the discussion, it can be suggested that understanding the organisational environment is an important factor in project success. Hence, the following hypotheses were proposed:

$\mathrm{Hla}_{0}$ : Understanding the environment in which the organisation operates does not influence the project outcome.

H1a: Understanding the environment in which the organisation operates positively influence the project outcome.

\section{Relationship of defining project objectives with project outcome}

According to Goetz (2010), vaguely defined objectives may lead the project into overruns, personality clashes, unhappy clients and missed milestones. Defining project objectives aids in aligning the organisation whereby the project objectives are clearly visible and understood, hence positive and negative risks in achieving the objectives are identified and understood and risk responses are aligned (Boubala, 2010). In support of this statement, Beleiu, Crisan and Nistor (2015) suggested that keeping project objectives in the vanguard of every project assures that the project and the team are on the same page during the project's life cycle. They concluded that clearly defined objectives enable the projects successful result. The proposed hypotheses were tested:

$\mathrm{Hlb}_{0}$ : Defining project objectives do not influence the project outcome.

Hlb: Defining project objectives positively influence the project outcome.

\section{Relationship of resource requirements with project outcome}

Muthuramalingam (2008) established that the availability of resources was a good predictor of risk management performance and, therefore, contributing to the successful completion of the project. Haughey (2014) study concluded that availability of resources influenced project success. Scheid (2011) stated that the project's resources need to be considered to keep on track with successful outcomes. This finding concurred with Manfredi and Auletta (2013) who indicated that the availability of resources had an impact on the decrease of cost overruns in projects. Therefore, the following hypotheses were postulated for testing:

$\mathrm{HlC}_{0}$ : Determining and documenting resource requirements do not positively influence the project outcome.

Hlc: Determining and documenting resource requirements positively influence the project outcome. 


\section{Relationship of risk measurement with project outcome}

Smit (2012) indicated that defining and documenting the risk measurement of a project was crucial to its success. He observed that risk measurement influences the outcome of the project in defining the risk measurement criteria to be used (high, medium or low), defining risk materiality (when risk is important), determining the level of acceptable risk and risk timeframe (when risk is likely to materialise). Phoya (2012) suggested that in order to successfully attain project objectives, a project team has to define a classification rule set (risk measurement) for each impact type that is relevant. In addition, Karimi et al. (2010) argued that risk measurement criteria were an advanced activity of risk management system; when it is used, it reduces risk impact on the project regarding schedule, budget as well as quality. Therefore, the proposed hypotheses were:

$\mathrm{Hld}_{0}$ : Defining and documenting the risk measurement to be used in assessing risk does not influence the project outcome.

$\mathrm{Hld}$ : Defining and documenting the risk measurement to be used in assessing risk has a direct positive influence on the project outcome.

\section{Relationship of risk identification with project outcome}

The results of Al-Shibly, Louzi and Hiassat (2013) indicated that risk identification influenced the project outcome. Martins (2006), de Bakker, Boonstra and Wortmann (2011) and Kloss-Grote and Moss (2008) observed that, as management implication escalates during risk identification, the risk of unclear scope of work seems to lessen and enhance project performance and consequently, influence positively project outcome. In addition, de Bakker, Boonstra and Wortmann (2011) indicated that individual risk management activity, risk identification, contributes to project success. They further inferred that the collaboration between project members during risk identification has a positive impact on the perceived success of the project. From the previous discussion, it can be said that there is a relationship between risk identification and project success; hence, the following hypotheses were tested:

$\mathrm{Hle}_{0}$ : The risk identification process does not have a positive influence on project outcome.

Hle: The risk identification process has a positive influence on project outcome.

\section{Relationship of risk assessment with project outcome}

In testing the correlation between risk assessment and planned budget, Al-Shibly, Louzi and Hiassat (2013) concluded that there was a significant impact of risk assessment on project planned budget. In order to abate the rise of unsuccessful project completion in construction, the importance of risk assessment is a fundamental factor in an organisation risk management practices as emphasised by several authors (Smit, 2012; Zeng and Smith, 2007; El-Sayegh, 2008; Abu Mousa, 2008) who affirmed the influence of risk assessment on the successful completion of a project. They reported that, by assessing risk, managers can distinguish between 
acceptable and unacceptable risk events and as a result enable them to capture and process information to assist them in the development of a risk management strategy (Lee-Anne, 2007; Oztas and Okmen, 2005; Nieto-Morote and Ruz-Vila, 2011 ; Karimi et al., 2010). Likewise, Naidoo (2012), indicated that risk assessment once performed, improved project objectives, accurate schedule, improved communication between relevant parties and hence increased the chance of project success (Naidoo, 2012). Therefore, the proposed hypotheses were:

$\mathrm{Hlf}_{0}$ : The risk assessment process does not have a positive influence on project outcome.

HIf: The risk assessment process has a positive influence on project outcome.

\section{Relationship of risk responses and action planning with project outcome}

Al-Rousan, Sulaiman and Salam (2010) argued that no construction project is riskfree; that if a project is successful, it is successful because appropriate responses were developed which led to the successful completion of the project. Kutsch and Hall (2005) study established that project performance can be enhanced by developing mitigating procedures which positively influence risk response for project success. Alberto and Timur (2013) believed that when conducted, risk responses change the risk profile through the project life cycle and risk exposure reduces. Omphile (2011) and Aimable (2015) established that risk response activities are strongly linked to the success of construction projects. The following hypotheses were suggested for testing:

$\mathrm{Hlg}$ : The risk response and action planning do not influence positively project outcome.

Hlg: The risk response and action planning positively influence the project outcome.

\section{Relationship of communication with project outcome}

Communication plays a major role in the success of any business. Silvius and Tharp (2013) indicated that communication between project head and management is fundamental and should be considered for the success of projects. In fact, without adequate communication, problems can occur because of distrust and conflict of interest (Naidoo, 2012), differences between national or ethnic cultures, including language, as well as different corporate cultures (Manitshana, 2012; Adnan and Morledge, 2003). According to de Bakker, Boonstra and Wortmann (2011), in situations where risks are not shared openly, the positively communicative effect may not materialise, hence, stifling the success of a project. The hypotheses formulated for tested were:

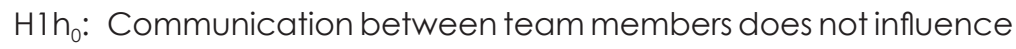
the project outcome.

H1h: Communication between team members positively influences the project outcome. 


\section{Relationship of monitoring, review and continuous improvement with project outcome}

Kamau and Mohamed (2015) and Hwang and Lim (2013) established that project monitoring and review allow management to verify that the control actions that were applied are efficacious to achieve project success. If controls actions are found to be ineffective, these should be revised, or new control actions implemented, thus enabling continuous improvement in future projects (DEAT [Department of Environmental Affairs and Tourism], 2006). Rezakhani (2012) found that project monitoring and continuous improvement is, even more, critical than planning in achieving project success. Equally many researchers (Andersen and Terp, 2006; Chin, 2012) concluded that one of the elements of the project management methodology whose main aim is to achieve project success is monitoring project progress. Therefore, the proposed hypotheses to be tested were:

$\mathrm{H}_{1 \mathrm{i}}$ : Monitoring, review and continuous improvement do not influence the project outcome.

H1i: Monitoring, review and continuous improvement positively influence the project outcome.

\section{RESEARCH METHOD}

In order to achieve the research objective, a quantitative research approach was adopted using a structured questionnaire to identify risk management factors and performance outcome in construction projects. This survey method was chosen over other survey methods such as direct observations and interviews because it allows the researcher to collect data on more sensitive information and participants who may be unwilling to discuss particular information with someone face-to-face, may be willing to answer such questions in a written survey (Agumba, 2013). In this study, sensitive information such as the company turnover, the number of permanent employees and the extent to which the company performs risk management activities were crucial for the purpose of the study. Furthermore, not only this method is less expensive but also the participants can take as much times as they need to answer the questions without feeling the pressure of someone waiting for the answer (Leedy and Ormrod, 2010).

The structure of the questionnaire comprised a cover letter which explained clearly the purpose of the study and five sections. Sections 1 to 4 reported respectively on basic information about the respondent and the company, project risks, obstacles to implementing risk management practices in construction projects and risk management practices. The last section which is at the heart of this article consisted of questions related to risk management factors and performance outcome of projects. There were 43 measures that defined 9 risk management factors identified from an extant literature review. Respondents were required to rate the extent to which their company performs the identified measures, based on a 5-point Likert-type scale. The scale was: 1 = "To No Extent", 2 = "A Low Extent", 3 = "A Moderate Extent", 4 = "A Large Extent" and 5 = "A Very Large Extent". Likewise, performance outcome was rated on a 5-point Likert-type scale where: 1 = "Very Poor" (VP), 2 = "Poor" (P), 3 = "Average" (A) , 4 = "Good" (G) and 5 = "Excellent" 
(E). Here, respondents were required to rate their company's performance on the identified project outcome measures

Prior to commencing the study, the questionnaire was tested with 10 professionals who had adequate knowledge of risk management factors used in construction projects. This was to ensure the content validity of the questionnaire. Minor changes were made to the piloted questionnaire and 225 questionnaires of the final questionnaire were disseminated to construction SMEs who were conveniently sampled in the Gauteng province of South Africa. The surveyed contractors were graded from Grade 1 to 6 (indicating small to medium enterprise) of the CIDB grading system, employing 50 to 200 permanent employees and with different area of business. The data was collected using email, drop and collect method, of which 187 questionnaires were returned and 181 were deemed usable representing approximately $80 \%$ response rate. The current response rate is high. This could have been because of using two methods to collect the data. It can, therefore, be indicated that the current response rate is appropriate and acceptable for analysis.

The Statistical Package for the Social Science (SPSS) version 23 was employed for data analysis. Descriptive and inferential statistical analyses were performed, which included frequency values and percentages and regression coefficients respectively. Descriptivestatisticswere used toreporton the respondent's background information including their individual information and the company information. EFA was used to establish the validity and reliability of the risk management factors and performance measures. Cronbach alpha was used to assess the reliability of data. A generally agreed upon minimum limit for Cronbach alpha is 0.70 (Hair et al., 2006). However, a cut-off value of 0.60 is common for exploratory research and values closer to 1 suggest good reliability (Zaiontz, 2014). This was achieved in this study, indicating that the instrument was reliable. The Oblimin with Kaiser normalisation rotation techniques were adopted as the extraction and rotation methods in the EFA. Multiple regression analysis (MRA) was used to determine the influence of risk management factors on performance outcome of SMEs construction projects.

\section{RESULTS AND DISCUSSION}

\section{Descriptive Statistics}

Among the respondents, $81.80 \%$ was male while $18.20 \%$ was female and $87.56 \%$ were either owners or managers of their enterprise. Based on the results, $56.40 \%$ of the respondents were African or Black, while $43.60 \%$ were Asian or Indian (9.90\%), Coloured (7.70\%) or White (26\%). For educational background, $22.90 \%$ had matriculation, $2.80 \%$ had no qualification and $14.50 \%$ of respondents had attended basic schooling. It is further shown that only $59.80 \%$ of respondents had post-secondary school qualification; of which $1.70 \%$ had a Doctorate degree, $6.10 \%$ had a Master's degree, $15.10 \%$ had an Honours/Bachelor of Technology (BTech)/Bachelor of Sciences (BSC) degree, 16.20\% had a Higher National Diploma/ Diploma and $20.70 \%$ had another certificate. In terms of years of experience in construction, type of contractor and business location, it was found that $77.80 \%$ of respondents had 20 years of experience or less, $16.80 \%$ had experience between 21 and 35 years and $5.40 \%$ had over 36 years of experience in construction. $38.20 \%$ of these contractors were sub-contractors, $32 \%$ were general contractors and $29.80 \%$ were either civil contractors $(6.70 \%)$, specialist contractors (18\%) or home 
building contractors (5.10\%). The majority $(72.30 \%)$ of the respondents operate in either Johannesburg (41.40\%) or Tshwane (30.90\%) Metropolitan Municipalities, while the remaining operates in either Ekurhuleni Metropolitan Municipality $(10.50 \%)$ or West Rand District Municipality (17.20\%). These results indicate the involvement of SMEs in various types of business and that the sub-contractors either operated for the main contractor or were sole trade contractors.

\section{Reliability Results}

Reliability of the data was achieved by determining the internal consistency of the variable using Cronbach's alpha. The Cronbach's alpha coefficients ranged between 0.825 and 0.935 for risk management factors and between 0.659 and 0.852 for project outcome measures, suggesting good reliability of the constructs (Pallant, 2013). The Kaiser-Meyer-Olkin (KMO) measure of sampling adequacy indicate coefficients that ranged between 0.712 and 0.849 for risk management factors and a coefficient of 0.815 for project success outcome. These values are above the threshold suggested by Pallant (2013). Furthermore, Bartlett's test of sphericity was statistically significant at $p=0.000(<0.05)$ for both risk management factors and project success outcome. These results supported the factorability of the correlation matrix (Pallant, 2013), indicating that the data of the study is suitable for factor analysis (FA).

\section{Results from EFA}

This section presents results from EFA. For ease of analysis, each measure was assigned a code as shown in Table 2. It is evinced that each of the components extracted accounted for a total variance of above $50 \%$ with an Eigenvalue above 1 (as shown in Table 2). The first of the components (organisational environment) is defined by 4 variables and accounted for $76.83 \%$ of the total variance of the risk management factors. The variables are: (1) "Identify and assess the internal environment factors", (2) "Identify and assess the external environment factors", (3) "Use the organisational business information system to document the internal and external environment" and (4) "Understand the internal environment which concerns all factors influencing the way firms manage risks". The second component is "defining objectives" and is measured by 4 variables, explaining $83.96 \%$ of the variance and accounting for $83.96 \%$ of the total variance to the risk management factors. The third component (resource requirement) accounted for $72.13 \%$ of the total variance and is defined by five measures. The fourth component, "risk measurement" contributed $79.70 \%$ of the total variance to the risk management factors and is defined by 5 variables. The fifth component is called "risk identification" and accounted for $66.06 \%$ of the total variance and is measured by 4 variables. The sixth component, "risk assessment" is measured by 5 variables and contributed $73.38 \%$ of the total variance to the risk management factors. The seventh component (risk response and action planning) was explained by 6 variables and accounted for $58.20 \%$ of the total variance to the risk management factors. The eighth component was defined by 4 variables and was called "communication" which has a contribution of $70.68 \%$ of the total variance. The last component, "monitoring, review and continuous improvement" explained $70.80 \%$ of the variance and accounted for $70.80 \%$ of the total variance to the risk management factors. The component was defined by five variables. 
Table 2. EFA Results of Risk Management Factors

\begin{tabular}{|c|c|c|c|c|}
\hline Factor & Eigenvalue & $\begin{array}{l}\text { Variance } \\
\%\end{array}$ & Variables & $\begin{array}{l}\text { Factor } \\
\text { Loading }\end{array}$ \\
\hline \multirow[t]{4}{*}{$\begin{array}{l}\text { Organisational } \\
\text { environment (OE) }\end{array}$} & 3.073 & 76.831 & $\begin{array}{l}\text { OEl: Identify and assess the internal } \\
\text { environment factors }\end{array}$ & 0.878 \\
\hline & & & $\begin{array}{l}\text { OE2: Identify and assess the external } \\
\text { environment factors }\end{array}$ & 0.943 \\
\hline & & & $\begin{array}{l}\text { OE3: Use the organisation business } \\
\text { information system to document the } \\
\text { internal and external environment }\end{array}$ & 0.912 \\
\hline & & & $\begin{array}{l}\text { OE4: Understand the internal environment, } \\
\text { which concerns all factors influencing } \\
\text { the manner in which firms manage risks }\end{array}$ & 0.762 \\
\hline \multirow[t]{4}{*}{$\begin{array}{l}\text { Defining } \\
\text { objectives (DO) }\end{array}$} & 3.358 & 83.959 & $\begin{array}{l}\text { DO1: Define the organisational focus, e.g. } \\
\text { organisational objectives and strategy }\end{array}$ & 0.877 \\
\hline & & & $\begin{array}{l}\text { DO2: Define the objectives and } \\
\text { methodology of the risk management } \\
\text { process }\end{array}$ & 0.940 \\
\hline & & & $\begin{array}{l}\text { DO3: Determine how the responsibility and } \\
\text { accountability for the risk management } \\
\text { process can be defined }\end{array}$ & 0.900 \\
\hline & & & $\begin{array}{l}\text { DO4: Determine how the effectiveness of } \\
\text { the risk management process can be } \\
\text { assessed }\end{array}$ & 0.947 \\
\hline \multirow[t]{5}{*}{$\begin{array}{l}\text { Resource } \\
\text { requirement (RR) }\end{array}$} & 3.606 & 72.126 & $\begin{array}{l}\text { RR1: Consider the personnel availability and } \\
\text { know-how }\end{array}$ & 0.906 \\
\hline & & & $\begin{array}{l}\text { RR2: Consider time requirement in terms of } \\
\text { scheduling risk meetings/workshops }\end{array}$ & 0.822 \\
\hline & & & $\begin{array}{l}\text { RR3: Consider information system } \\
\text { requirement in identifying risks, } \\
\text { implementing controls and follow-up } \\
\text { activities }\end{array}$ & 0.850 \\
\hline & & & $\begin{array}{l}\text { RR4: Consider risk communication } \\
\text { mechanism, e.g., informal discussions, } \\
\text { company newsletter }\end{array}$ & 0.814 \\
\hline & & & $\begin{array}{l}\text { RR5: Consider technology requirements, } \\
\text { e.g., use of spreadsheets, risk profile }\end{array}$ & 0.852 \\
\hline \multirow[t]{5}{*}{$\begin{array}{l}\text { Risk measurement } \\
\text { (RM) }\end{array}$} & 3.985 & 79.700 & $\begin{array}{l}\text { RM1: Define the risk measurement criteria to } \\
\text { be used, e.g., high/medium/low }\end{array}$ & 0.841 \\
\hline & & & $\begin{array}{l}\text { RM2: Define risk materiality, e.g., when risk is } \\
\text { important }\end{array}$ & 0.873 \\
\hline & & & $\begin{array}{l}\text { RM3: Define risk timeframe applicable to risk } \\
\text { impact and risk probability, e.g., when } \\
\text { risk is expected to occur }\end{array}$ & 0.887 \\
\hline & & & 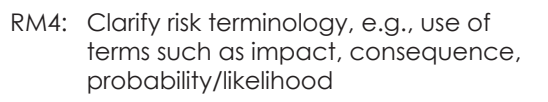 & 0.941 \\
\hline & & & $\begin{array}{l}\text { RM5: Determine the level of acceptable } \\
\text { risk, e.g., the risk tolerance level of the } \\
\text { firm }\end{array}$ & 0.920 \\
\hline
\end{tabular}


Table 2. (continued)

\begin{tabular}{|c|c|c|c|c|}
\hline Factor & Eigenvalue & $\begin{array}{l}\text { Variance } \\
\%\end{array}$ & Variables & $\begin{array}{l}\text { Factor } \\
\text { Loading }\end{array}$ \\
\hline \multirow[t]{4}{*}{$\begin{array}{l}\text { Risk identification } \\
\text { (RI) }\end{array}$} & 2.642 & 66.057 & $\begin{array}{l}\text { RI1: Develop risk information database, } \\
\text { e.g., information gathering, risk history } \\
\text { database }\end{array}$ & 0.818 \\
\hline & & & RI2: Identify how and why risk arises & 0.839 \\
\hline & & & $\begin{array}{l}\text { RI3: Conduct present and future risk } \\
\text { identification, e.g., develop risk register } \\
\text { information quality, management } \\
\text { techniques }\end{array}$ & 0.861 \\
\hline & & & $\begin{array}{l}\text { RI4: Use physical inspection to identify the } \\
\text { risk }\end{array}$ & 0.725 \\
\hline \multirow[t]{5}{*}{$\begin{array}{l}\text { Risk assessment } \\
\text { (RA) }\end{array}$} & 3.669 & 73.379 & $\begin{array}{l}\text { RA 1: Determine the risk cause, risk duration, } \\
\text { risk volatility }\end{array}$ & 0.850 \\
\hline & & & $\begin{array}{l}\text { RA2: Determine the probability of the risk } \\
\text { occurring, the impact, classification } \\
\text { consistency, e.g., high/medium/low }\end{array}$ & 0.843 \\
\hline & & & $\begin{array}{l}\text { RA3: Establish the risk profile, e.g., high } \\
\text { probability/high impact, high } \\
\text { probability/low impact }\end{array}$ & 0.907 \\
\hline & & & $\begin{array}{l}\text { RA4: Assess risks by quantitative analysis } \\
\text { methods, e.g., probability, sensitivity, } \\
\text { scenario, simulation analysis }\end{array}$ & 0.899 \\
\hline & & & $\begin{array}{l}\text { RA5: Assess risks by qualitative analysis } \\
\text { methods, e.g., direct judgement, } \\
\text { comparing option, descriptive analysis }\end{array}$ & 0.777 \\
\hline \multirow{6}{*}{$\begin{array}{l}\text { Risk response and } \\
\text { action planning } \\
\text { (RP) }\end{array}$} & 3.492 & 58.198 & $\begin{array}{l}\text { RP1: Identify risk treatment options by } \\
\text { avoiding risk }\end{array}$ & 0.699 \\
\hline & & & $\begin{array}{l}\text { RP2: Identify risk treatment options by } \\
\text { mitigating risk }\end{array}$ & 0.657 \\
\hline & & & $\begin{array}{l}\text { RP3: Identify risk treatment options by } \\
\text { retaining risk }\end{array}$ & 0.742 \\
\hline & & & $\begin{array}{l}\text { RP4: Identify risk treatment options by } \\
\text { transferring risk }\end{array}$ & 0.696 \\
\hline & & & $\begin{array}{l}\text { RP5: Predefine actions to counter the } \\
\text { identified project risks }\end{array}$ & 0.582 \\
\hline & & & RP6: Prepare and implement risk action plan & 0.727 \\
\hline \multirow[t]{4}{*}{$\begin{array}{l}\text { Communication } \\
\text { (C) }\end{array}$} & 2.828 & 70.680 & $\begin{array}{l}\text { C1: Establish a communication process for } \\
\text { interactive (two-way) consultation with } \\
\text { stakeholders }\end{array}$ & 0.796 \\
\hline & & & $\begin{array}{l}\text { C2: Establish a communication process } \\
\text { for two-way consultation with external } \\
\text { stakeholders }\end{array}$ & 0.743 \\
\hline & & & $\begin{array}{l}\text { C3: Establish a crisis communication strategy } \\
\text { facilitating immediate information } \\
\text { exchange }\end{array}$ & 0.641 \\
\hline & & & $\begin{array}{l}\text { C4: Develop a communication evaluation } \\
\text { mechanism }\end{array}$ & 0.870 \\
\hline
\end{tabular}


Table 2. (continued)

\begin{tabular}{|c|c|c|c|c|}
\hline Factor & Eigenvalue & $\begin{array}{c}\text { Variance } \\
\%\end{array}$ & Variables & $\begin{array}{l}\text { Factor } \\
\text { Loading }\end{array}$ \\
\hline \multirow{5}{*}{$\begin{array}{l}\text { Monitoring, review } \\
\text { and continuous } \\
\text { improvement } \\
\text { (MR) }\end{array}$} & 3.540 & 70.796 & $\begin{array}{l}\text { MR1: Assign responsibility for monitoring and } \\
\text { review actions }\end{array}$ & 0.830 \\
\hline & & & $\begin{array}{l}\text { MR2: Identify and select monitoring and } \\
\text { review techniques }\end{array}$ & 0.912 \\
\hline & & & $\begin{array}{l}\text { MR3: Assess control effectiveness, measured } \\
\text { in terms of meeting departmental/ } \\
\text { organisational objectives }\end{array}$ & 0.777 \\
\hline & & & $\begin{array}{l}\text { MR4: Do control enhancement by revising } \\
\text { ineffective controls identified }\end{array}$ & 0.826 \\
\hline & & & $\begin{array}{l}\text { MR5: Report the new results from monitoring } \\
\text { and review activities }\end{array}$ & 0.856 \\
\hline
\end{tabular}

Note: Extraction method: EFA; Rotation method: Oblimin with Kaiser normalisation

\section{EFA Results of Project Outcome}

Table 3 presents the EFA results of SMEs project success outcome. Three of the five variables of project success outcome had Eigenvalues above 1 (1.954, 1.217 and 1.003 ), explaining $39.08 \%, 24.35 \%$, and $20.06 \%$ of the variance and accounting for $83.49 \%$ of the total variance to a successful outcome. These results indicate that success outcome of SMEs project is defined by three variables namely: (1) "Meeting time objectives for key milestones", (2) "Meeting cost objectives for the project" and (3) "Meeting quality objectives for the project". The decision to retain the three variables was further supported by using Oblimin with Kaiser normalisation rotation method which evinced strong loadings of the variables. Hence, enough evidence of convergent validity was provided for this construct.

Table 3. EFA Results of the Successful Outcome of SMEs Construct Projects

\begin{tabular}{lcccc}
\hline Component & Variable & Eigenvalue & \% Explained Variance & Factor Loading \\
\hline & PO1 & 1.954 & 39.079 & 0.790 \\
& PO2 & 1.217 & 24.350 & 0.890 \\
Project outcome & PO3 & 1.003 & 20.064 & 0.913 \\
(PO) & PO4 & 0.501 & 10.020 & 0.936 \\
& PO5 & 0.324 & 6.487 & 0.612 \\
\hline
\end{tabular}

Note: Extraction method: EFA; Rotation method: Oblimin with Kaiser normalisation 


\section{The Results from MRA}

\section{Influence of organisational environment on project outcome}

From Table 4, two measures (OEl and OE4) of organisational environment were statistically significant at the 0.05 level (OEl $p=0.010$; OE4 $p=0.038$ ). Of the two measures, OEl made a larger significant unique contribution $(\beta=0.346)$. The beta value for OE4 was lower $(-0.211)$, indicating that it made less of a unique contribution to project outcome.

Table 5 shows that organisational environment explained $20 \%\left(R^{2}=0.198\right)$ of the variance in project success at the project level of SMEs. This suggests that organisational environment was not a good predictor of project success because of the low $R^{2}$ achieved. However, the analysis of variance (ANOVA) results (as shown in Table 6) further indicated that the model reached statistical significance at $p=0.000$ (i.e. <0.05). This indicates that project outcome was influenced by the two measures (OEl and OE4) and the influence of organisational environment is significantly different from the value of 10.887 ( $F$-value). Therefore, the null hypothesis $\left(\mathrm{Hla}_{0}\right)$ that organisational environment does not influence project outcome cannot be supported. This means that the alternate hypothesis $(\mathrm{Hl}$ a) that organisational environment positively influences project outcome may be true.

Table 4. Coefficients-Influence of Organisational Environment on Project Outcome

\begin{tabular}{lccccccc}
\hline \multirow{2}{*}{ Model } & \multicolumn{2}{c}{ Unstandardised } & & Standardised & & Sig. & Zero-Order Correlations \\
\cline { 2 - 3 } (Constant) & $\mathbf{B}$ & Std. Error & & $\boldsymbol{\beta}$ & & \\
OE1 & 19.364 & 0.276 & & & 0.000 & \\
OE2 & 0.381 & 0.146 & & 0.346 & 0.010 & 0.422 \\
OE3 & 0.176 & 0.188 & & 0.140 & 0.350 & 0.321 \\
OE4 & 0.100 & 0.174 & & 0.074 & 0.567 & 0.345 \\
\hline
\end{tabular}

Table 5. Model Summary-Influence of Organisational Environment on Project Outcome

\begin{tabular}{ccccc}
\hline Model & $\boldsymbol{R}$ & $\boldsymbol{R}^{\mathbf{2}}$ & Adjusted $\boldsymbol{R}^{\mathbf{2}}$ & Std. Error of the Estimate \\
\hline & 0.445 & 0.198 & 0.180 & 1.33582 \\
\hline
\end{tabular}

Table 6. ANOVA-Influence of Organisational Environment on Project Outcome

\begin{tabular}{lccccc}
\hline & Sum of Squares & df & Mean Square & $\boldsymbol{F}$ & Sig. \\
\hline Regression & 77.709 & 4 & 19.427 & 10.887 & 0.000 \\
Residual & 314.059 & 176 & 1.784 & & \\
\hline Total & 391.768 & 180 & & & \\
\hline
\end{tabular}




\section{Influence of defining objectives on project outcome}

From Table 7, two measures (DO1 and DO2) of defining objectives were statistically significant at the 0.05 level (DO1 $p=0.047$; OE4 $p=0.028$ ). Of the two measures, DO2 made a larger significant unique contribution of $34 \%(\beta=0.338)$. The beta value for DOI was lower at $24 \%(\beta=0.238)$, indicating that it made less of a unique contribution to project outcome.

Table 8 shows that defining project objectives explained $15 \%\left(R^{2}=0.145\right)$ of the variance in project success at SMEs level. This suggests that the independent variable namely defining objectives was not a good predictor of project success because of the low $R^{2}$ achieved. Nevertheless, the ANOVA results (as shown in Table 9) further indicated that the model reached statistical significance at $p=0.000$ (i.e. $<0.05$ ). This indicates that project outcome was influenced by the two measures (DO1 and DO2) of defining project objectives and the influence of defining project objectives is significantly different from the value of 7.443 ( $F$-value). Therefore, the null hypothesis $\left(\mathrm{Hlb}_{0}\right)$ that defining project objectives does not influence project outcome cannot be supported. This means that the alternate hypothesis ( $\mathrm{Hl}$ b) could not be rejected.

Table 7. Coefficients-Influence of Defining Objectives on Project Outcome

\begin{tabular}{lccccccc}
\hline \multirow{2}{*}{ Model } & \multicolumn{2}{c}{ Unstandardised } & & Standardised & & Sig. & Zero-order Correlations \\
\cline { 2 - 3 } (Constant) & $\mathbf{B}$ & Std. Error & & $\boldsymbol{\beta}$ & & \\
DO1 & 0.922 & 0.316 & & & 0.000 & \\
DO2 & 0.472 & 0.212 & & 0.338 & 0.028 & 0.346 \\
DO3 & -0.193 & 0.165 & & -0.155 & 0.243 & 0.341 \\
DO4 & -0.087 & 0.206 & & -0.068 & 0.672 & 0.218 \\
\hline
\end{tabular}

Table 8. Model Summary-Influence of Defining Objectives on Project Outcome

\begin{tabular}{ccccc}
\hline Model & $\boldsymbol{R}$ & $\boldsymbol{R}^{\mathbf{2}}$ & Adjusted $\boldsymbol{R}^{2}$ & Std. Error of the Estimate \\
\hline & 0.380 & 0.145 & 0.125 & 1.37981 \\
\hline
\end{tabular}

Table 9. ANOVA-Influence of Defining Objectives on Project Outcome

\begin{tabular}{lcrccc}
\hline & Sum of Squares & \multicolumn{1}{c}{ df } & Mean Square & $\boldsymbol{F}$ & Sig. \\
\hline Regression & 56.686 & 4 & 14.171 & 7.443 & 0.000 \\
Residual & 335.082 & 176 & 1.904 & & \\
\hline Total & 391.768 & 180 & & & \\
\hline
\end{tabular}




\section{Influence of resource requirement on project outcome}

As shown in Table 10, only one measure (RR4) of resource requirement was significant at the 0.05 level (i.e. $p=0.005<0.05$ ). The measure recorded $a$ significant unique contribution to the variance of $33 \%(\beta=0.326)$. Furthermore, Table 11 shows that the five measures of resource requirement model explained $14 \%\left(R^{2}=0.139\right)$ of the variance in project success at SMEs project level. Although this is not a lot of explanation in the dependent variable, the ANOVA results (as shown in Table 12) indicated statistical significance of the model; the significance p-value was 0.000 which was less than the recommended value of 0.05 . This indicated that project outcome was influenced by only one measure (RR4) of resource requirement and the influence of resource requirement is significantly different from the value of 5.636 ( $F$-value). Since the influence was significant, the null hypothesis $\left(\mathrm{HlC}_{0}\right)$ that resource requirement does not influence project outcome could not be supported. Hence, the alternate hypothesis $(\mathrm{HlC})$ could not be rejected.

Table 10. Coefficients-Influence of Resource Requirement on Project Outcome

\begin{tabular}{|c|c|c|c|c|c|}
\hline \multirow{2}{*}{ Model } & \multicolumn{2}{|c|}{ Unstandardised } & \multirow{2}{*}{$\frac{\text { Standardised }}{\beta}$} & \multirow{2}{*}{ Sig. } & \multirow{2}{*}{ Zero-Order Correlations } \\
\hline & $B$ & Std. Error & & & \\
\hline (Constant) & 18.808 & 0.374 & & 0.000 & \\
\hline RR1 & -0.129 & 0.172 & -0.109 & 0.455 & 0.134 \\
\hline RR2 & 0.284 & 0.169 & 0.192 & 0.094 & 0.287 \\
\hline RR3 & -0.089 & 0.152 & -0.071 & 0.560 & 0.113 \\
\hline RR4 & 0.493 & 0.173 & 0.326 & 0.005 & 0.339 \\
\hline RR5 & -0.033 & 0.142 & -0.230 & 0.818 & 0.161 \\
\hline
\end{tabular}

Table 11. Model Summary-Influence of Resource Requirement on Project Outcome

\begin{tabular}{ccccc}
\hline Model & $\boldsymbol{R}$ & $\boldsymbol{R}^{2}$ & Adjusted $\boldsymbol{R}^{2}$ & Std. Error of the Estimate \\
\hline & 0.372 & 0.139 & 0.114 & 1.38860 \\
\hline
\end{tabular}

Table 12. ANOVA-Influence of Resource Requirement on Project Outcome

\begin{tabular}{lcrccc}
\hline & Sum of Squares & df & Mean Square & $\boldsymbol{F}$ & Sig. \\
\hline Regression & 54.333 & 5 & 10.867 & 5.636 & 0.000 \\
Residual & 337.435 & 175 & 1.928 & & \\
\hline Total & 391.768 & 180 & & & \\
\hline
\end{tabular}




\section{Influence of risk measurement on project outcome}

Table 13 indicates that, of the five measures (RM1, RM2, RM3, RM4 and RM5) of risk measurement, only one measure (RM3) reached statistical significance at the 0.05 level (i.e. $p=0.052<0.05$ ). The measure had a significant unique contribution of $28 \%$ ( $\beta=0.281$ ) presented in Table 13. It was further found that risk measurement explained $13 \%\left(R^{2}=0.130\right)$ of the variance in project outcome at SMEs level (as shown in Table 14). This suggested that risk measurement was not a good predictor of project success because of the low $R^{2}$ achieved. However, the ANOVA results (as shown in Table 15) indicated that the model reached statistical significance at $p=0.000$ (i.e. $<0.05$ ). This indicated that project outcome was influenced by one measure (RM3) and the influence of risk measurement is significantly different from the value of 5.227 ( $F$-value). Therefore, the null hypothesis $\left(\mathrm{Hld}_{0}\right)$ that risk measurement does not influence project outcome could not be supported. Therefore, the alternate hypothesis $(\mathrm{Hld})$ may be true.

Table 13. Coefficients-Influence of Risk Measurement on Project Outcome

\begin{tabular}{|c|c|c|c|c|c|}
\hline \multirow{2}{*}{ Model } & \multicolumn{2}{|c|}{ Unstandardised } & \multirow{2}{*}{$\frac{\text { Standardised }}{\beta}$} & \multirow{2}{*}{ Sig. } & \multirow{2}{*}{ Zero-Order Correlations } \\
\hline & B & Std. Error & & & \\
\hline (Constant) & 19.098 & 0.310 & & 0.000 & \\
\hline RMI & 0.166 & 0.150 & 0.135 & 0.269 & 0.310 \\
\hline RM2 & -0.218 & 0.164 & -0.188 & 0.186 & 0.152 \\
\hline RM3 & 0.362 & 0.185 & 0.281 & 0.052 & 0.339 \\
\hline RM4 & 0.024 & 0.214 & 0.019 & 0.912 & 0.261 \\
\hline MR5 & 0.081 & 0.193 & 0.075 & 0.674 & 0.216 \\
\hline
\end{tabular}

Table 14. Model Summary-Influence of Risk Measurement on Project Outcome

\begin{tabular}{ccccc}
\hline Model & $\boldsymbol{R}$ & $\boldsymbol{R}^{\mathbf{2}}$ & Adjusted $\boldsymbol{R}^{\mathbf{2}}$ & Std. Error of the Estimate \\
\hline & 0.360 & 0.130 & 0.105 & 1.39564 \\
\hline
\end{tabular}

Table 15. ANOVA-Influence of Risk Measurement on Project Outcome

\begin{tabular}{lcrccc}
\hline & Sum of Squares & df & Mean Square & $\boldsymbol{F}$ & Sig. \\
\hline Regression & 50.901 & 5 & 10.180 & 5.227 & 0.000 \\
Residual & 340.866 & 175 & 1.948 & & \\
\hline Total & 391.768 & 180 & & & \\
\hline
\end{tabular}




\section{Influence of risk identification on project outcome}

Table 16 presents the regression coefficients. It was found that three measures (RI2 $p=0.003$, RI3 $p=0.003$ and $\mathrm{RI} 4 \mathrm{p}=0.047$ ) were found to have a significant unique contribution to explaining the dependent variable project success. The measures RI2 and RI3 made an equal and the largest significant unique contribution of $32 \%$ ( $\beta=0.032$ and 0.322 , respectively), while the beta value for RI4 was lower $(-0.182)$ indicating that it made less of a unique contribution.

Table 17 evinced that $R^{2}=0.173$. This indicated that $17 \%$ of the variance in project success can be explained by the four risk identification measures. Furthermore, Table 18 shows that the significance $p$-value attained was 0.000 , which was less than the recommended value of 0.05 . This indicated that project outcome was influenced by three measures of risk identification (RI2, RI3 and RI4) and that the influence is significantly different from the value of 9.031 ( $F$-value). Consequently, the null hypothesis $\left(\mathrm{Hle}_{0}\right)$ that risk identification has no influence on project outcome was rejected. This means that hypothesis $\mathrm{Hle}$ could not be rejected.

Table 16. Coefficients-Influence of Risk Identification on Project Outcome

\begin{tabular}{|c|c|c|c|c|c|}
\hline \multirow{2}{*}{ Model } & \multicolumn{2}{|c|}{ Unstandardised } & \multirow{2}{*}{$\frac{\text { Standardised }}{\beta}$} & \multirow{2}{*}{ Sig. } & \multirow{2}{*}{ Zero-Order Correlations } \\
\hline & B & Std. Error & & & \\
\hline (Constant) & 18.607 & 0.431 & & 0.000 & \\
\hline RII & -0.173 & 0.152 & -0.116 & 0.257 & 0.225 \\
\hline $\mathrm{RI} 2$ & 0.487 & 0.160 & 0.321 & 0.003 & 0.354 \\
\hline $\mathrm{RI3}$ & 0.497 & 0.163 & 0.322 & 0.003 & 0.327 \\
\hline $\mathrm{R} \mid 4$ & -0.257 & 0.129 & -0.182 & 0.047 & 0.111 \\
\hline
\end{tabular}

Table 17. Model Summary-Influence of Risk Identification on Project Outcome

\begin{tabular}{ccccc}
\hline Model & $\boldsymbol{R}$ & $\boldsymbol{R}^{2}$ & Adjusted $\boldsymbol{R}^{2}$ & Std. Error of the Estimate \\
\hline & 0.416 & 0.173 & 0.154 & 1.36522 \\
\hline
\end{tabular}

Table 18. ANOVA-Influence of Risk Identification on Project Outcome

\begin{tabular}{lcrccc}
\hline & Sum of Squares & df & Mean Square & $\boldsymbol{F}$ & Sig. \\
\hline Regression & 67.332 & 4 & 16.833 & 9.031 & 0.000 \\
Residual & 322.443 & 173 & 1.864 & & \\
\hline Total & 389.775 & 177 & & & \\
\hline
\end{tabular}




\section{Influence of risk assessment on project outcome}

As illustrated in Table 19, one measure (RA2) of risk assessment was found to be significant (i.e. $p=0.000<0.05$ ), making the largest significant contribution of $56 \%$ $(\beta=0.566)$. The results in Table 20 show risk assess explained $19 \%\left(R^{2}=0.186\right)$ of the variance in project success at SMEs level. This suggested that risk assessment was not a good predictor of project outcome because of the low $R^{2}$ achieved.

However, the ANOVA results in Table 21 indicated that the model reached statistical significance at $p=0.000$ (i.e. $<0.05$ ). This indicated that project outcome was influenced by one measure (RA2) of risk assessment and that the influence was significantly different from the value of 7.997 ( $F$-value). Thus, the null hypothesis $\left(\mathrm{H}_{\mathrm{f}} \mathrm{f}_{\mathrm{o}}\right)$ that risk assessment does not influence project success could not be supported. This means that the hypothesis ( $\mathrm{Hlf}$ ) could not be rejected.

Table 19. Coefficients-Influence of Risk Assessment on Project Outcome

\begin{tabular}{|c|c|c|c|c|c|}
\hline \multirow{2}{*}{ Model } & \multicolumn{2}{|c|}{ Unstandardised } & \multirow{2}{*}{$\frac{\text { Standardised }}{\beta}$} & \multirow{2}{*}{ Sig. } & \multirow{2}{*}{ Zero-Order Correlations } \\
\hline & B & Std. Error & & & \\
\hline (Constant) & 18.836 & 0.394 & & 0.000 & \\
\hline RAl & -0.057 & 0.151 & -0.044 & 0.706 & 0.246 \\
\hline RA2 & 0.794 & 0.158 & 0.566 & 0.000 & 0.398 \\
\hline RA3 & -0.268 & 0.157 & -0.221 & 0.090 & 0.153 \\
\hline RA4 & 0.038 & 0.171 & 0.027 & 0.826 & 0.210 \\
\hline RA5 & -0.005 & 0.141 & -0.004 & 0.973 & 0.107 \\
\hline
\end{tabular}

Table 20. Model Summary-Influence of Risk Assessment on Project Outcome

\begin{tabular}{ccccc}
\hline Model & $\boldsymbol{R}$ & $\boldsymbol{R}^{\mathbf{2}}$ & Adjusted $\boldsymbol{R}^{\mathbf{2}}$ & Std. Error of the Estimate \\
\hline 0.431 & 0.186 & 0.163 & 1.34992 \\
\hline
\end{tabular}

Table 21. ANOVA-Influence of Risk Assessment on Project Outcome

\begin{tabular}{lcrccc}
\hline & Sum of Squares & df & Mean Square & $\boldsymbol{F}$ & Sig. \\
\hline Regression & 72.868 & 5 & 14.574 & 7.997 & 0.000 \\
Residual & 318.900 & 175 & 1.822 & & \\
\hline Total & 391.768 & 180 & & & \\
\hline
\end{tabular}

\section{Influence of risk response and action planning on project outcome}

Table 22 presents the regression coefficients. It was found that four measures (RP1, RP3, RP4 and RP5) were statistically significant at the 0.05 level ( $p=0.004, p=0.038$, $p=0.004$ and $p=0.013$, respectively). The measure RP 4 made the largest significant contribution of $24 \%$ ( $\beta=0.240$ ) while RP3 recorded a low score of -0.181 , indicating that it made less of a unique contribution. 
Table 23 evinced that $R^{2}=0.195$, which indicated that $20 \%$ of the variance in project outcome can be explained by risk response and action planning. This model value reached statistical significance (i.e. $p=0.000<0.05$ ) (as shown in Table 24). This suggested that project outcome was influenced by four measures (RP1, RP3, RP4 and RP5) of risk response and action planning and that the influence was significantly different from the value of 6.908. Therefore, the null hypothesis that risk response and action planning have no influence on project outcome, $\mathrm{Hlg}_{0}$, can, therefore, be rejected. This means that it is probable that risk response and action planning positively influence project success. Hence, hypothesis $\mathrm{H} l \mathrm{~g}$ could not be rejected.

Table 22. Coefficients-Influence of Risk Response Planning on Project Outcome

\begin{tabular}{|c|c|c|c|c|c|}
\hline \multirow{2}{*}{ Model } & \multicolumn{2}{|c|}{ Unstandardised } & \multirow{2}{*}{$\frac{\text { Standardised }}{\beta}$} & \multirow{2}{*}{ Sig. } & \multirow{2}{*}{ Zero-Order Correlations } \\
\hline & $B$ & Std. Error & & & \\
\hline (Constant) & 19.034 & 1.090 & & 0.000 & \\
\hline $\mathrm{RP} 1$ & 0.645 & 0.220 & 0.228 & 0.004 & 0.196 \\
\hline RP2 & -0.179 & 0.170 & -0.081 & 0.296 & -0.090 \\
\hline RP3 & -0.282 & 0.135 & -0.181 & 0.038 & -0.195 \\
\hline RP4 & -0.433 & 0.148 & -0.240 & 0.004 & -0.283 \\
\hline RP5 & 0.346 & 0.138 & 0.214 & 0.013 & 0.123 \\
\hline RP6 & 0.210 & 0.180 & 0.106 & 0.244 & 0.127 \\
\hline
\end{tabular}

Table 23. Model Summary-Influence of Risk Response Planning on Project Outcome

\begin{tabular}{ccccc}
\hline Model & $\boldsymbol{R}$ & $\boldsymbol{R}^{\mathbf{2}}$ & Adjusted $\boldsymbol{R}^{\mathbf{2}}$ & Std. Error of the Estimate \\
\hline & 0.442 & 0.195 & 0.167 & 1.35394 \\
\hline
\end{tabular}

Table 24. ANOVA-Influence of Risk Response Planning on Project Outcome

\begin{tabular}{lccccc}
\hline & Sum of Squares & df & Mean Square & $\boldsymbol{F}$ & Sig. \\
\hline Regression & 75.975 & 6 & 12.663 & 6.908 & 0.000 \\
Residual & 313.468 & 171 & 1.833 & & \\
\hline Total & 389.444 & 177 & & & \\
\hline
\end{tabular}

\section{Influence of communication on project outcome}

Table 25 presents the regression coefficients of the influence of communication on project success. It was evinced that only one measure (C4) of communication was found to be statistically significant ( $p=0.038$ ), making a significant unique contribution of $17 \%(\beta=0.172)$. Although the model in Table 26 revealed that $3.8 \%$ $\left(R^{2}=0.038\right)$ of the variance in project outcome can be explained by the four measures of communication. 
The ANOVA results in Table 27 indicated that the significance p-value achieved was 0.145 , which was greater than the recommended value of less than 0.05. Therefore, the null hypothesis $\mathrm{HIh}_{0}$ could not be rejected. This means that project outcome may not be influenced by communication; hence, hypothesis $\mathrm{H} 1 \mathrm{~h}$ could not be supported.

Table 25. Coefficients-Influence of Communication on Project Outcome

\begin{tabular}{|c|c|c|c|c|c|}
\hline \multirow{2}{*}{ Model } & \multicolumn{2}{|c|}{ Unstandardised } & \multirow{2}{*}{$\frac{\text { Standardised }}{\beta}$} & \multirow{2}{*}{ Sig. } & \multirow{2}{*}{ Zero-Order Correlations } \\
\hline & B & Std. Error & & & \\
\hline (Constant) & 19.209 & 0.943 & & 0.000 & \\
\hline $\mathrm{Cl}$ & 0.156 & 0.213 & 0.066 & 0.466 & 0.112 \\
\hline $\mathrm{C} 2$ & 0.036 & 0.154 & 0.021 & 0.817 & 0.024 \\
\hline C3 & -0.124 & 0.210 & -0.048 & 0.553 & 0.010 \\
\hline $\mathrm{C} 4$ & 0.216 & 0.103 & 0.172 & 0.038 & 0.177 \\
\hline
\end{tabular}

Table 26. Model Summary-Influence of Communication on Project Outcome

\begin{tabular}{ccccc}
\hline Model & $\boldsymbol{R}$ & $\boldsymbol{R}^{\mathbf{2}}$ & Adjusted $\boldsymbol{R}^{\mathbf{2}}$ & Std. Error of the Estimate \\
\hline & 0.195 & 0.038 & 0.016 & 1.46343 \\
\hline
\end{tabular}

Table 27. ANOVA-Influence of Communication on Project Outcome

\begin{tabular}{lcrccc}
\hline & Sum of Squares & \multicolumn{1}{c}{ df } & Mean Square & $\boldsymbol{F}$ & Sig. \\
\hline Regression & 14.841 & 4 & 3.710 & 1.732 & 0.145 \\
Residual & 376.927 & 176 & 2.142 & & \\
\hline Total & 391.768 & 180 & & & \\
\hline
\end{tabular}

Influence of monitoring, review and continuous improvement on project outcome

Regression results presented in Table 28 indicated that of the five measures (MR 1 , MR2, MR3, MR4 and MR5) only two items (MR3 $p=0.013$ and MR4 $p=0.000$ ) were statistically significant at 0.05 level. Of the two measures, MR4 made the largest significant unique contribution of $66 \%(\beta=0.066)$ while MR3 made a low score of $\beta=-0.244$. This result indicated that MR3 made less of $a$ unique contribution.

Table 29 further shows that this factor explained $29 \%\left(R^{2}=0.286\right)$ of the variance in project outcome at SMEs level. The ANOVA results (as shown in Table 30) indicated that the model reached statistical significance at $p=0.000$ (i.e. < 0.05). This result indicated that project outcome was influenced by two measures (MR3 and MR4) of monitoring and reviews and that this influence was significantly different by the value of 14.001 (F-value). Consequently, the null hypothesis $\left(\mathrm{Hli}_{0}\right)$ that project monitoring, review and continuous improvement do not influence project success could not be supported. This means that the alternate hypothesis (Hli) could not be rejected. 
Table 28. Coefficients-Influence of Monitoring and Review Process on Project Outcome

\begin{tabular}{|c|c|c|c|c|c|}
\hline \multirow{2}{*}{ Model } & \multicolumn{2}{|c|}{ Unstandardised } & \multirow{2}{*}{$\frac{\text { Standardised }}{\beta}$} & \multirow{2}{*}{ Sig. } & \multirow{2}{*}{ Zero-Order Correlations } \\
\hline & B & Std. Error & & & \\
\hline (Constant) & 18.532 & 0.505 & & 0.000 & \\
\hline MRI & -0.292 & 0.183 & -0.182 & 0.113 & 0.278 \\
\hline MR2 & -0.084 & 0.205 & -0.051 & 0.684 & 0.219 \\
\hline MR3 & -0.413 & 0.165 & -0.244 & 0.013 & 0.094 \\
\hline MR4 & 1.000 & 0.155 & 0.660 & 0.000 & 0.484 \\
\hline MR5 & 0.286 & 0.159 & 0.190 & 0.074 & 0.268 \\
\hline
\end{tabular}

Table 29. Model Summary-Influence of Monitoring and Review Process on Project Outcome

\begin{tabular}{ccccc}
\hline Model & $\boldsymbol{R}$ & $\boldsymbol{R}^{\mathbf{2}}$ & Adjusted $\boldsymbol{R}^{\mathbf{2}}$ & Std. Error of the Estimate \\
\hline 0.535 & 0.286 & 0.265 & 1.26452 \\
\hline
\end{tabular}

Table 30. ANOVA-Influence of Monitoring, Review and Continuous Improvement on Project Outcome

\begin{tabular}{lcrccc}
\hline & Sum of Squares & df & Mean Square & $\boldsymbol{F}$ & Sig. \\
\hline Regression & 111.941 & 5 & 22.388 & 14.001 & 0.000 \\
Residual & 279.827 & 175 & 1.599 & & \\
\hline Total & & 180 & & & \\
\hline
\end{tabular}

\section{DISCUSSION}

The relationship of risk management factors known to influence project outcome in construction has scarcely been conducted empirically. Whether project outcome is influenced by the known factors and to what extent, are poorly documented. The current study was carried out to elucidate those questions. MRA established eight significant relationships which are depicted in Figure 2. Organisational environment is significant ( $\beta=0.346, p=0.000<0.05$ ) in influencing project success aligns with findings from Basu et al. (2002) who also established that factors such as organisational environment, stakeholder's involvement and team implication are significantly linked with project success. This was an indication that understanding the environment in which the organisation operates is an important risk management factor that influences project success.

The relationship between defining project objectives and project outcome was significant $(\beta=0.338, p=0.000<0.05)$. This means that defining project objectives positively influenced the project outcome. This result concurs with the findings of Boubala (2010), Goetz (2010), Beleiu, Crisan and Nistor (2015). Beleiu, 
Crisan and Nistor (2015) incorporated defining project objectives as part of the risk management system. A Risk management system is important in an organisation because, without it, a firm cannot possibly define its objectives for the future. It can be argued that defining project objectives among SMEs is an important risk management factor influencing performance outcome at the project level of SMEs.

Project outcome was influenced by resource requirements, indicating that there is a significant relationship $(\beta=0.326, p=0.000<0.05)$ between both variables. This finding concurs with findings from other studies such as those of Scheid (2011) and Haughey (2014), who tested the relationship of risk management resources and project performance and established that risk management resources were significant in achieving project performance. Beleiv, Crisan and Nistor (2015) also established that risk management resources such as tools and techniques and the provision of employees' incentives influenced project success. It can be argued that lack of resource requirement may compromise projects from achieving preestablished objectives. Hence, it is always vital to ensure availability of resources during projects.

The relationship between the independent variable risk measurement and the dependent variable project success was significant $(\beta=0.281, p=0.000<0.05)$. This was an indication that project success was influenced by risk measurement practice. This finding was like those of Smit (2012) and Phoya (2012). Smit (2012) observed that risk measurement influences the outcome of the project. This is achieved by defining the risk measurement criteria to be used, determining the level of acceptable risk and risk timeframe applicable to risk impact and risk probability.

The relationship between risk identification and project success was significant $(\beta=0.321, p=0.000<0.05)$. This implied that risk identification influenced the project outcome. The results of de Bakker, Boonstra and Wortmann (2011) and Al-Shibly, Louzi and Hiassat (2013) supported the current results. De Bakker, Boonstra and Wortmann (2011) established that when risk identification is executed in a brainstorming setting, it can create awareness and common observation among stakeholders, which results in actions that are synchronised and, consequently, more effective. Furthermore, Martins (2006) and Kloss-Grote and Moss (2008) findings supported the current findings by observing that as management involvement increases in risk identification, the risk of unclear or misunderstood scope seems to lessen and enhance project performance and hence influence positively the project outcome.

The relationship between risk assessment and project success was found to be significant ( $\beta=0.566, p=0.000<0.05$ ), indicating that risk assessment positively influenced the project outcome. This finding concurs with those of Roque and de Carvalho (2013) and Al-Shibly, Louzi and Hiassat (2013). In addition, Al-Shibly, Louzi and Hiassat (2013) established that there is a positive impact on risk assessment and project planned budget. Likewise, the current result is supported by the study of Aimable (2015) which indicated that risk assessment conducted, increases the project performance in achieving project set goals.

The relationship between risk response and action planning recorded a significant relationship $(\beta=0.228, p=0.000<0.05)$, implying that risk response and action planning positively influence performance outcome at the project level. This finding corroborates with that of Aimable (2015), Al-Shibly, Louzi and Hiassat (2013) and Alberto and Timur (2013) where risk response was found to be positively linked with project success. In addition, Phoya (2012), incorporated risk response and 
action planning as part of their risk management system and was referred to as risk treatment. The author established that risk treatment had a direct positive influence on the success of a project.

Communication between project members did not record a statistical significance $(\beta=0.172, p=0.145>0.05)$ and therefore was not identified as a critical factor to enable success in construction. This implies that communication between project participants does not influence the success of the project. The current finding was contrary to the findings of several authors such as Omphile (2011), Naidoo (2012) and Phoya (2012) who established that communication has a direct positive influence on the success of any business. Phoya (2012) believed that projects to succeed, there is an incessant need for effective communication to issue instructions, solve problems, make decisions, resolve conflicts and keep all stakeholders involved with the project supplied with the latest information. Arguably communication (both oral and written) is critical to project success as confirmed in several studies.

The relationship between monitoring, review and continuous improvement with project success was found to be significant $(\beta=0.660, p=0.000<0.05$ ), suggesting that the practice of monitoring, review and continuous improvement positively influence the success of a project. This finding is in line with those of Papke-Shield, Beise and Quan (2010) and Hwang and Lim (2013). In addition, Phoya (2012) and Gajewska and Ropel (2011) incorporated project monitoring, review and continuous improvement as part of their risk management strategy and was referred to as project review. Monitoring, review and continuous improvement as such enhance the project management decision making during the implementation phase thus securing the success of the project (Phoya, 2012).

The resulting significant relationships between the variables are summarised in Figure 2. The study recommends that top management of construction SMEs should ensure that risk management factors are implemented not as routine activities but as a requirement of managing construction projects effectively and efficiently.

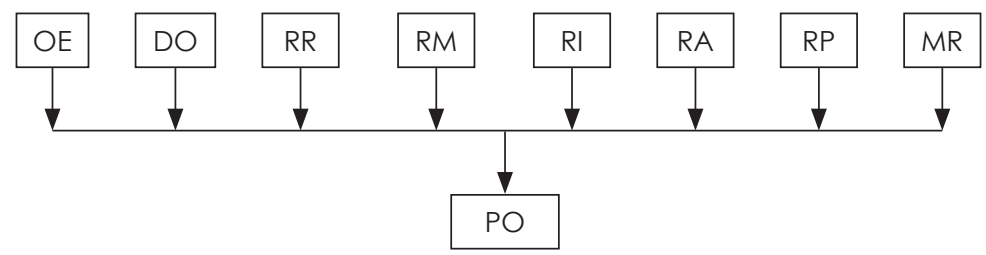

Figure 2. Significant Relationships of Risk Management Factors That Influence Project Outcome of Construction SMEs

Note: OE (organisational environment), DO (defining objectives), RR (resource requirement), RM (risk measurement), RI (risk identification), RA (risk assessment); RP (risk response and action planning) and MR (monitoring, review and continuous improvement): All independent variables; PO (project outcome): Dependent variable.

$\longrightarrow$ : Accepted hypotheses that are a significant relationship. 


\section{CONCLUSION AND RECOMMENDATIONS}

This article sought to determine the influence of risk management factors on performance outcome of SMEs construction projects in the South African construction industry. Based on the findings, it is evident that of the nine hypotheses tested, eight could not be rejected and one was rejected. This implies that performance outcome at the project level of construction SMEs were found to be influenced positively by eight risk management factors. The influential factors were organisational environment, defining project objectives, resource requirement, risk measurement, risk identification, risk assessment, risk response and action planning, and monitoring, review and continuous improvement. These results corroborate with extant literature, suggesting that SMEs are aware of the significance of risk management factors to the performance outcome of their projects.

It is important to note that the rejected factor "communication" was defined by 4 variables and contributed $70.68 \%$ of the total variance. However, it did not influence the performance outcome of SMEs construction projects. Therefore, it can be deduced that SMEs do not view "communication" as a core factor of risk management influencing performance outcome at their project level. This result is surprising as it is not in line with extant literature which advocates communication as a non-negotiable factor that is central to the success of any business. Building on the above, it can, therefore, be concluded that the main purpose of the study was achieved.

The eight significant relationships that influenced success at the project level of SMEs are summarised in Figure 2. These relationships are an indicator of an ideal construction risk management model for SMEs at the project level. Hence, it can be postulated that these factors are the non-negotiable risk management factors that influence performance outcome of projects. Therefore, an indication of risk management culture leading indicator factors at the project level of construction SMEs. In conclusion, the risk management factors established in this study can be used as points of reference for SMEs to achieve success in construction projects.

\section{DELIMITATION OF THE STUDY AND FURTHER RESEARCH}

The study was conducted in South Africa; however, it was delimited to the province of Gauteng. The surveyed respondents were small and medium (graded 1 to 6) construction enterprises registered with the CIDB. Therefore, care should be taken to not generalise the results of this study across all SMEs in South Africa, nor they cannot be extended to other categories of contractors. However, the findings indicate that the study will contribute to the related body of knowledge. Further studies may be undertaken in South Africa will cover the whole country or the same study may be replicated in other countries.

\section{ACKNOWLEDGEMENT}

The authors wish to thank small and medium contractors for participating in this study. Without their participation, this study would not have been conducted. We also wish to acknowledge the financial support from the University of Johannesburg in conducting this study. 


\section{REFERENCES}

Abu Mousa, E.J.H. (2008). Risk management in construction projects from contractors and owners' perspectives. MSc diss. Islamic University of Gaza.

Adnan, H. and Morledge, R. (2003). Joint venture projects in Malaysian construction industry: Factors critical to success. In D.J. Greenwood (ed.), 19th Annual ARCOM Conference. Vol. 2. Brighton, UK: Association of Researchers in Construction Management, 765-774.

Agle, K. (2013). 4 elements of an effective enterprise risk management program. CUlnsight, 28 May. Available at: https://www.cuinsight.com/4-elements-ofan-effective-enterprise-risk-management-program.html [Accessed on 28 July 2019].

Agumba, J.N. (2013). A construction health and safety performance improvement model for South African small and medium enterprises. PhD diss. University of Johannesburg.

(2006). Evaluating the use of project management techniques in infrastructure delivery by South African small and medium sized contractors. MTech diss. University of Johannesburg.

Aigbavboa, C.O., Tshikhudo, L.M. and Thwala, W.D. (2014). Identification of critical success factors for the survival of small, medium and micro enterprise contracting firms in the greater Johannesburg Metropolitan area. Paper presented at the 8th Construction Industry Development Board Postgraduate Conference. Johannesburg, South Africa, 10-11 February.

Aimable, S. (2015). Effects of risk management methods on project performance in Rwandan construction industry: A case study of the multi-storey buildings construction project of RSSB. MSC diss. University of Agriculture and Technology (Kigali Campus).

Alberto, M. and Timur, N. (2013). Earned value-based performance monitoring of facility construction projects. Journal of Facilities Management, 11 (1): 69-80. https://doi.org/10.1108/14725961311301475.

Al-Rousan, T., Sulaiman, S. and Salam, R.A. (2010). WPRiMA tool: Managing risks in web projects. International Journal of Business, Economics, Finance and Management Science, 8(8): 1-8

Al-Shibly, H.H., Louzi, B.M. and Hiassat, M.A. (2013). The impact of risk management on construction projects success from the employees' perspective. Interdisciplinary Journal of Contemporary Research in Business, 5(4): 12-43.

Andersen, K. and Terp, A. (2006). Risk Management: Perspectives on Strategic Risk Management. Copenhagen: Copenhagen Business School Press.

Basu, V., Hartono, E., Lederer, A.L. and Sethi, V. (2002). The impact of organisational commitment, senior management involvement and team involvement in strategic information systems planning. Information and Management, 39(6): 513-524. https://doi.org/10.1016/S0378-7206(01)00115-X.

Beasley, S.M., Clune, R. and Hermanson, D.R. (2005). Enterprise risk management: An empirical analysis of factors associated with the extent of implementation. Journal of Accounting and Public Policy, 24(6): 521-531. https://doi.org/ 10.1016/j.jaccpubpol.2005.10.001.

Beleiv, I., Crisan, E. and Nistor, R. (2015). Main factors influencing project success. Interdisciplinary Management Research, 11:59-72. 
Berssaneti, F.T. and Carvalho, M.M. (2015). Identification of variables that impact project success in Brazilian companies. International Journal of Project Management, 33(3): 638-649. https://doi.org/10.1016/j.ijproman.2014.07.002.

Bilich, T. (2015). Elements of an effective risk management process. RiskAlternatives, 12 October. Available at: https://riskalts.com/the-7-elements -of-an-effective-risk-management-process/ [Accessed on 28 July 2019].

Bosher, L., Dainty, A., Carrillo, P., Glass, J. and Price, A. (2007). Integrating disaster risk management into construction: A UK perspective. Journal of Building Research and Information, 35(2): 163-177. https://doi.org/10.1080/ 09613210600979848.

Boubala, H.G.O. (2010). Risk management of SMMEs. MTech diss. Cape Peninsula University of Technology.

Cambridge Advanced Learner's Dictionary (2008). Cambridge: Cambridge University Press.

Chen, J. (2006). Development of Chinese small and medium-sized enterprises. Journal of Small Business and Enterprise Development, 13(2): 140-147. https://doi.org/10.1108/14626000610665854.

Chin, C.M.M. (2012). Development of a project management methodology for use in a university-industry collaborative research environment. PhD diss. University of Nottingham.

Chou, J.S. and Pham, A.D. (2013). Project management knowledge of construction professionals: Cross-country study of effects on project success, Journal of Construction Engineering and Management, 139(11): 04013015-104013015-15. https://doi.org/10.1061/(ASCE)CO.1943-7862.0000766.

Chou, J.S. and Yang, J.G. (2012). Project management knowledge and effects on construction project outcomes: An empirical study. Project Management Journal, 43(5): 47-67. https://doi.org/10.1002/pmj.21293.

CIDB (Construction Industry Development Board) (2011). Annual Reports 2010-2011. Pretoria: CIDB.

Collins, A. and Baccarini, D. (2004). Project success: A survey. Journal of Construction Research, 5(2): 211-231. https://doi.org/10.1142/S1609945104000152.

de Bakker, K., Boonstra, A. and Wortmann, H. (2011). Risk management affecting IS/IT project success through communicative action. Project Management Journal, 42(3): 75-90. https://doi.org/10.1002/pmj.20242.

DEAT (Department of Environmental Affairs and Tourism) (2006). Risk Management, Integrated Environmental Management Information Series 23. Pretoria: DEAT.

Deloach, J. (2018). Key elements of the risk management process. Corporate Compliance Insights, 10 January. Available at: https://www. corporatecomplianceinsights.com/key-elements-of-the-risk-managementprocess/ [Accessed on 28 July 2019].

Dlungwana, W.S., Noyana, C., Nxumalo, X.H., Rwelamila, P.D. and van Huysteen, S. (2002). Development and implementation of the South African Construction Excellence Model (SACEM). Paper presented at the International Conference on Construction in the 21st Century: Challenges and Opportunities in Management and Technology. Miami, Florida, 26-26 April.

El-Gohary, N.M., Osman, H. and El-Diraby, T.E. (2006). Stakeholder management for public-private partnerships. International Journal of Project Management, 24(7): 595-604. https://doi.org/10.1016/j.ijproman.2006.07.009. 
El-Sayegh, S. (2008). Risk assessment and allocation in the UAE construction. International Journal of Project Management, 26(4): 431-438. https://doi .org/10.1016/j.ijproman.2007.07.004.

Eyiah, A. (2001). An integrated approach to financing small contractors in developing countries: A conceptual model. Journal of Construction Management and Economics, 19(5): 511-518. https://doi.org/10.1080/ 01446193.2001 .9709627$.

Fan, Q. (2003). Importance of SMEs and the role of public support in promoting SME development. Paper presented at the Creating a Conductive Legal and Regulatory Framework for Small and Medium Enterprise Development in Russia: A Policy Dialogue Workshop. St. Petersburg, Russia, 14-16 September.

Fischer, R. (2015). Barriers to effective risk management on small construction projects in South Africa. MSc diss. University of the Witwatersrand.

Gajewska, E. and Ropel, M. (2011). Risk management practices in construction project: A case study. MSc diss. Chalmers of Technology.

Gao, S.S., Sung, M.C. and Zhang, J. (2011). Risk management capability building in SMEs: A social capital perspective. International Small Business Journal, 31 (6): 677-700. https://doi.org/10.1177/0266242611431094.

Goetz, R. (2010). Defining project goals and objectives. Available at: https://www. projectsmart.co.uk/defining-project-goals-andobjectives.php [Accessed on 7 January 2016].

Gordon, L.A., Loeb, M.P and Tseng, C.Y. (2009). Enterprise risk management and firm performance: A contingency perspective. Journal of Accounting and Public Policy, 28(4): 301-327. https://doi.org/10.1016/j.jaccpubpol.2009.06.006.

Government of South Africa (1996). National Small Business Act 102 of 1996. Cape Town: Government of South Africa.

Hair, J.F., Black, W.C., Babin, J.B., Andersen, R.E. and Taham, R.I. (2006). Multivariate Data Analysis. 6th Ed. Upper Saddle River, NJ: Pearson/Prentice Hall.

Haughey, D. (2014). Eight key factors to ensuring project success. Available at: https://www.projectsmart.co.uk/white-papers/eight-key-factors-to-ensuringproject-success.pdf [Accessed on 12 March 2016].

Hinze, J., Thurman, S. and Wehle, A. (2013). Leading indicators of construction safety performance. Safety Science, 51(1): 23-28. https://doi.org/10.1016/j. ssci.2012.05.016.

Hwang, B. and Lim, E. (2013). Critical success factors for key project players and objectives: Case study of Singapore. Journal of Construction, Engineering Management, 139(2): 204-215. https://doi.org/10.1061/(ASCE)CO.19437862.0000597.

Immaneni, A., Mastro, C. and Haubenstock, M. (2004). A structured approach to building predictive key risk indicators. Available at: https://cms.rmau. org/uploadedFiles/Credit_Risk/Library/RMA_Journal/Operational_Risk_ Topics/A\%20Structured\%20Approach\%20to\%20Building\%20Predictive\%20 Key\%20Risk\%20Indicators.pdf [Accessed on 28 July 2019].

Jablonowski, M. (2001). Thinking in numbers. Risk Management, 48(2): 30-35.

Kamau, C.G. and Mohamed, H.G. (2015). The efficacy of monitoring and evaluation function in achieving project success in Kenya. Science Journal of Business and Management, 3(3): 82-94. https://doi.org/10.11648/j.sjbm.20150303.14.

Karimi, A., Mousavi, N., Mousavi, S. and Hosseini, S. (2010). Risk assessment model selection in construction industry. Expert Systems with Applications, 38(2): 9105-9111. https://doi.org/10.1016/j.eswa.2010.12.110. 
Kishan, P., Bhatt, R. and Bhavsar, J.J. (2014). A study of risk factors affecting building construction projects. International Journal of Engineering Research and Technology, 3(12): 831-835.

Kloss-Grote, B. and Moss, M. (2008). How to measure the effectiveness of risk management in engineering design projects? Presentation of RMPASS: A new method for assessing risk management performance and the impact of knowledge management-including a few results. Research in Engineering Design, 19(2/3): 71-100. https://doi.org/10.1007/s00163-008-0049-y.

Kutsch, E. and Hall, M. (2005). Intervening conditions on the management of project risk: Dealing with uncertainty in information technology projects. International Journal of Project Management, 23(8): 591-599. https://doi.org/10.1016/j.jpproman.2005.06.009.

Lee-Anne, P. (2007). The impact of risk management on the changing nature of principal's work. PhD diss. Queensland University of Education.

Leedy, D.P. and Ormrod, E.J. (2010). Practical Research: Planning and Designing. 9th Ed. Upper Saddle River, NJ: Pearson Education.

Liebenberg, A.P. and Hoyt, R.E. (2003). The determinants of enterprise risk management: Evidence from the appointment of chief risk officers. Risk Management and Insurance Review, 6(1): 37-52. https://doi.org/10.1111/ 1098-1616.00019.

Luo, Y.D. (2003). Industrial dynamics and managerial networks in an emerging market: The case of China. Strategic Management Journal, 24(13): 13151327. https://doi.org/10.1002/smj.363.

Mahendra, P.A., Pitroda, J.R. and Bhavsar, J.J. (2013). A study of risk management techniques for construction projects in developing countries. International Journal of Innovation Technology and Exploring Engineering, 3(5): 139-142.

Manfredi, R. and Auletta, J. (2013). The importance of resource management for any successful project plan. Available at: http://community .bamboosolutions.com/media/p/58056.aspx [Accessed on 10 January 2016].

Manitshana, B. (2012). Assessment of the critical success factors of joint ventures in the South African construction industry. MTech diss. University of Johannesburg.

Marcelino-Sádaba, S., Pérez-Ezcurdia, A., Echeverría Lazcano, A.M., Villanueva, P. (2014). Project risk management methodology for small firms. International Journal of Project Management, 32: 327-340. https://doi.org/10.1016/j. ijproman.2013.05.009.

Martin, L. (2010). Transfer Mechanisms of Knowledge and Skills in Co-Operations between Emerging and Established Civil Engineering Contractors. Cape Town: Department of the Built Environment, Cape Peninsula University of Technology.

Martins, C.G. (2006). Aplicação das técnicas de identificação de risco em projetos de $\mathrm{E}$ and $\mathrm{P}$. MBA diss. Universidade Federal Fluminense.

Masutha, M. and Rogerson, C.M. (2014). Small business incubators: An emerging phenomenon in South Africa's SMME economy. Urbani Izziv, 25: 47-62. https://doi.org/10.5379/urbani-izziv-en-2014-25-supplement-004.

Momeni, M., Hamidizade, M.R. and Nouraei, R. (2015). Identification and prioritization of effective intra-project and environmental challenges on project management system: Case study; Projects of pars special economic energy zone. Applied Mathematics, Management and Technology, 3(1): 414-422. 
Muthuramalingam, J. (2008). Effective resources management in construction industries for success. Modern Applied Science, 2(6): 41-48. https://doi.org/ $10.5539 /$ mas.v2n6p41.

Naidoo, P.K. (2012). The effects of risk management on the success of a project. MEM diss. University of Johannesburg.

Ngundo, J.M. (2014). Factors affecting effectiveness of risk management in public housing construction projects in Kenya: A case of Kibera slum upgrading housing scheme in Nairobi. MA diss. University of Nairobi.

Nieto-Morote A. and Ruz-Vila, F. (2011). A fuzzy approach to construction project risk assessment. International Journal of Project Management, 29(2): 220-231. https://doi.org/10.1016/j.jpproman.2010.02.002.

Olamiwale, I.O. (2014). Evaluation of risk management practices in the construction industry in Swaziland. MTech diss. Tshwane University of Technology.

Olander, S. and Landin, A. (2005). Evaluation of stakeholder influence in the implementation of construction projects. International Journal of Project Management, 23(4): 321-328. https://doi.org/10.1016/j.ijproman.2005.02.002.

Omphile, W. (2011). The implication of project risk management maturity on information technology project success. MTech diss. University of Johannesburg.

Oztas, A. and Okmen, O. (2005). Judgmental risk analysis process development in construction projects. Building and Environment, 40(9): 1244-1254. https://doi.org/10.1016/j.buildenv.2004.10.013.

Pallant, J. (2013). SPSS Survival Manual: A Step By Step Guide to Data Analysis Using IBM SPSS. 5th Ed. Crows Nest, NSW: Allen and Unwin.

Papke-Shields, K.E., Beise, C. and Quan, J. (2010). Do project managers practice what they preach and does it matter to project success? International Journal of Project Management, 28(7): 650-662. https://doi.org/10.1016/j. ijproman.2009.11.002.

Phoya, S. (2012). Health and safety risk management in building construction sites in Tanzania: The practice of risk assessment and control. Licentiate of Engineering diss. Chalmers University of Technology.

Poba-Nzaou, P. and Raymond, L. (2011). Managing ERP system risk in SMEs: A multiple case study. Journal of Information Technology, 26: 170-192. https://doi.org/10.1057/jit.2010.34.

Rezakhani, P. (2012). Current state of existing project risk modeling and analysis methods with focus on fuzzy risk assessment: Literature review. Frattura ed Integrità Strutturale, 6(20): 17-21. https://doi.org/10.3221/IGF-ESIS.20.02.

Roelen, A.L.C. and Klompstraa, M.B. (2012). The challenges in defining aviation safety performance indicators. Proceedings of the PSAM 11 \& ESREL 2012. Helsinki: Curran Associates, Inc.

Roque, R.Jr. and de Carvalho, M.M. (2013). Understanding the impact of project risk management on project performance: An empirical study. Journal of Technology Management and Innovation, 8(Suppl. 1): 6. https://doi.org/ 10.4067/S0718-27242013000300006.

Scarlat, E., Chirita, N. and Bradea, A.I. (2012). Indicators and metrics used in the enterprise risk management (ERM). Journal of Economic Computation and Economic Cybernetics Studies and Research, 45(4): 5-18.

Scheid, J. (2011). Do you understand your project's resources? Available at: http:// www.brighthubpm.com/resource-management/51791-do-you-understand -your-projects-resources/ [Accessed on 10 January 2016]. 
Silvius, G. and Tharp, J. (2013). Sustainability Integration for Effective Project Management. Pennsylvania: IGI Global.

Smit, Y. (2012). A structured approach to risk management for South African SMEs. PhD diss. Cape Peninsula University of Technology.

Statistics South Africa (2017). Quarterly Labour Force Survey: August 2017, Publication P0211. Pretoria: Statistics South Africa.

. (2014). Quarterly Labour Force Survey: Quarter 4, 2014. Pretoria: Statistics South Africa.

Toor, S. and Ogunlana, S. (2010). Beyond the iron triangle: Stakeholder perception of key performance indicators (KPIs) for large-scale public sector development projects. International Journal of Project Management, 28: 228-236. https://doi.org/10.1016/j.jproman.2009.05.005.

UN-Habitat (United Nations Centre for Human Settlements) (1996). An Urbanizing World: Global Report on Human Settlements. Oxford: Oxford University Press.

Van Scheers, L. (2011). SMEs marketing skills challenges in South Africa. African Journal of Business Management, 5(13): 5048-5056.

Verbano, C. and Venturini, K. (2013). Managing risks in SMEs: A literature review and research agenda. Journal of Technology Management and Innovation, 8(3): 186-197. https://doi.org/10.4067/S0718-27242013000400017.

Weninger, C., Huemann, M., Oliveira, J.C., Barros Filho, L.F.M. and Weitlaner, E. (2013). Experimenting with project stakeholder analysis: A case study. In A.J.G. Silvius and J. Tharp (eds.), Sustainability Integration for Effective Project Management. Pennsylvania: IGI Global, 380-393.

World Bank Group (2017). Small and medium enterprises (SMEs) finance, improving SMEs's access to finance and finding innovative solutions to unlock sources of capital. Available at: https://www.worldbank.org/en/topic/smefinance [Accessed on 29 July 2019].

Writer, S. (2018). The alarming truth about the number of small businesses in South Africa. Available at: https://businesstech.co.za/news/business/260797/ the-alarming-truth-about-the-number-of-small-businesses-in-south-africa/ [Accessed on 29 July 2019].

Zaiontz, C. (2014). Real statistics using Excel: Cronbach's alpha. Available at: https://www.real-statistics.com/reliability/internal-consistency-reliability/ cronbachs-alpha/.

Zeng, J. and Smith, N.J. (2007). Application of a fuzzy based decision-making methodology to construction project risk assessment. International Journal of Project Management, 25(6): 589-600. https://doi.org/10.1016/j. ijproman.2007.02.006. 